\title{
The effects of IGF-I on bovine follicle development and IGFBP-2 expression are dose and stage dependent
}

\author{
Kirsty A Walters, John P Binnie, Bruce K Campbell ${ }^{2}$, David G Armstrong ${ }^{1}$ and Evelyn E Telfer \\ Institute of Cell and Molecular Biology, Darwin Building, University of Edinburgh, King's Buildings, Mayfield Road, \\ Edinburgh EH9 3JR, UK, ${ }^{1}$ Division of Integrative Biology, Roslin Institute (Edinburgh), Roslin, Midlothian EH25 \\ 9PS, UK and ${ }^{2}$ School of Human Development, University of Nottingham, Queens Medical Centre, Nottingham \\ NG7 $2 \mathrm{VH}, \mathrm{UK}$ \\ Correspondence should be addressed to E E Telfer; Email: Evelyn.Telfer@ed.ac.uk
}

\begin{abstract}
This study aimed to determine the effect of insulin-like growth factor-I (IGF-I) on early antral bovine follicular development, and the expression of insulin-like growth factor-binding protein-2 (IGFBP-2). Antral follicles separated into three different size groups were cultured for 6 days in medium supplemented with either a low $(10 \mathrm{ng} / \mathrm{ml})$ or high $(1 \mu \mathrm{g} / \mathrm{ml})$ dose of human recombinant IGF-I. Oestradiol production by follicles in all size ranges, cultured in the presence of the high concentration of IGF-I, significantly increased by day $6(P<0.05)$. Follicles in the smallest size range, $165-215 \mu \mathrm{m}$, cultured in a high dose of IGF-I, were found to be significantly increased in size $(P<0.01)$. Oocyte health of the largest follicles $(281-380 \mu \mathrm{m})$ was significantly improved by the addition of IGF-I to the culture medium. mRNA expression of IGFBP-2 was decreased in the granulosa cells of follicles, size range $216-280 \mu \mathrm{m}$, cultured with a high dose of IGF-I $(P<0.05)$. Granulosa cells $(P<0.05)$ and oocytes $(P<0.01)$ of the largest follicles $(281-380 \mu \mathrm{m})$ showed a decrease in IGFBP-2 expression (protein) when cultured in the control and low-IGF-I treatment groups. Therefore, the response of a bovine follicle to IGF-I is both dose and stage dependent. This work supports a role for IGF-I in modulating somatic and germ-cell maturation and development in early antral follicles. Furthermore, the inverse relationship between the level of IGF-I stimulation and IGFBP-2 expression suggests a local regulatory system modulating IGF-I availability.

Reproduction (2006) 131 515-523
\end{abstract}

\section{Introduction}

The insulin-like growth factor (IGF) system has already been shown to play a key role in ovarian function (Giudice 1992, Poretsky et al. 1999). During follicle growth, IGF works in synergy with gonadotrophins (follicle-stimulating hormone (FSH) and luteinising hormone $(\mathrm{LH})$ ) to regulate proliferation and differentiation of granulosa and theca cells (Campbell et al. 1996, 1998, Gutierrez et al. 1997). Furthermore, an absolute requirement for IGF-I in female fertility has been demonstrated in experiments using IGF-I knockout mice, whose follicles were arrested at the late preantral/early antral stage and failed to respond to gonadotrophins (Baker et al. 1996, Zhou et al. 2000). In cattle, there does not seem to be an absolute requirement for IGF-I in antral formation, but it has been shown to be important at the antral stage of follicle development, where it is involved in the regulation of follicle growth, stimulation of somatic cell proliferation, and oestrogen, as well as progesterone biosynthesis (Armstrong \& Webb 1997, Webb et al. 1999). Nuclear maturation in the oocytes of cattle (Lorenzo et al. 1994) and pigs (Sirotkin et al. 2000) is enhanced by IGF-l; however, addition of IGF-I was not shown to improve nuclear or cytoplasmic maturation of sheep oocytes (Guler et al. 2000). Recent work has also outlined the beneficial effects of IGF-I in early follicle growth (Gutierrez et al. 2000, Louhio et al. 2000, Zhao et al. 2001, Itoh et al. 2002). However, although IGF has a stimulatory effect in early follicle growth, work by McCaffery et al. (2000) highlighted the importance of regulatory mechanisms, showing that inappropriate exposure of bovine preantral follicles to IGF-I has a detrimental effect on oocyte development.

IGF-I expression remains controversial, with reports demonstrating both its presence, at very low levels (Yuan et al. 1998), and absence (Armstrong et al. 2000). However, intense expression of mRNA encoding IGF-II in thecal tissue of bovine ovarian follicles has been detected (Armstrong \& Webb 1997), and a similar spatial distribution has been described in sheep (Perks et al. 1995). In the cow, IGF-II has been shown to be the principal 
intrafollicular IGF ligand (Armstrong et al. 2000). IGFbinding proteins (IGFBPs) regulate the availability of IGFs to their target cells by either inhibiting or potentiating their action (Giudice 1992). IGFBPs can sequester extracellular IGFs and hence reduce the bioavailability of IGF. However, two mechanisms by which facilitation of the IGFs can be increased is by the activity of specific IGFBP proteases and changes in the expression of the IGFBPs (Giudice 1992). At present, mRNA encoding IGFBP-2,-5 has been detected in bovine follicles (Armstrong \& Webb 1997, Armstrong et al. 1998, 2002), and IGFBP-2, -4 and -5 mRNA have been found in the ovine follicle (Besnard et al. 1996). IGFBP-2 mRNA has been found in the granulosa cells and oocytes of bovine preantral and early antral follicles (Armstrong et al. 2002), as well as the granulosa cells of larger antral follicles (1-8 $\mathrm{mm}$ ) (Armstrong et al. 1998). Furthermore, immunoreactive IGFBP-2 has been detected around granulosa cells from bovine follicles at the preantral stage (Armstrong et al. 2002), indicating that IGFBP-2 may be important in regulating bioavailability during early stages of follicular development.

The regulation of IGF-I bioavailability by IGFBPs is important for normal follicle and oocyte development. The detection of IGF-I binding in bovine preantral follicles (Wandji et al. 1992), coupled with the expression of type 1 IGF receptor and IGFBP-2 mRNA from the preantral stage (Spicer \& Echternkamp 1995, Perks et al. 1999, Armstrong et al. 2002), suggests a role for the IGF system in early follicle development. Therefore, it is important to understand the mechanisms involved in regulating the expression of IGFBPs and hence the availability of IGF to its receptors at different stages of growth. Changes in the effects of IGF-I (Campbell et al. 1996, Gutierrez et al. 1997) and the expression of IGFBPs from early to late follicle development (Monget et al. 1996) further support the view that the need for IGF-I stimulation is dependent on the stage of the developing follicle. The present study aimed to investigate the effect of IGF-I on early antral follicular development and the expression of IGFBP-2. In particular, follicle growth, oestradiol production and the expression of IGFBP-2 during the crucial transition phase from late preantral to early antral stage will be investigated.

\section{Materials and Methods}

\section{Antral follicle isolation}

Bovine ovaries from random stages of the oestrous cycle were obtained from a local abattoir and transported to the laboratory. During transit, they were maintained at $25-30^{\circ} \mathrm{C}$ in M199 (HEPES-buffered) medium (Gibco BRL, Life Technologies, Paisley, UK) supplemented with sodium pyruvate $(2 \mathrm{mM})$, glutamine $(2 \mathrm{mM}), B S A(3 \mathrm{mg} / \mathrm{ml})$, penicillin $\mathrm{G}(75 \mu \mathrm{g} / \mathrm{ml})$ and streptomycin $(50 \mu \mathrm{g} / \mathrm{ml})$ (all chemicals from Sigma unless otherwise stated). Upon arrival at the laboratory, the ovaries were placed under a laminar flow hood, rinsed in $70 \%$ alcohol and kept warm $\left(37^{\circ} \mathrm{C}\right)$ in an incubator. Underneath a laminar flow hood, fine slices $(\sim 1 \mathrm{~mm}$ wide) of ovarian cortex were taken with a scalpel and placed in dissection medium (Leibovitz's medium (Gibco BRL)) supplemented with sodium pyruvate $(2 \mathrm{mM})$, glutamine $(2 \mathrm{mM})$, Fraction $\vee$ BSA $(3 \mathrm{mg} / \mathrm{ml})$, penicillin $\mathrm{G}(75 \mu \mathrm{g} / \mathrm{ml})$ and streptomycin $(50 \mu \mathrm{g} / \mathrm{ml})$, and maintained at $37^{\circ} \mathrm{C}$. Early antral follicles were isolated from the cortical slices under a dissecting microscope with 25G needles and sorted into three size groups (small $(165-215 \mu \mathrm{m})$, medium $(216-280 \mu \mathrm{m})$ and large $(281-380 \mu \mathrm{m}))$. Approximately 40 follicles were isolated on each culture day. Follicles of a normal shape, with an intact basement membrane and no obvious signs of degeneration, were selected for culture. The time taken for collection of ovaries from the abattoir to the start of the culture period was a maximum of $6 \mathrm{~h}$.

\section{Follicle culture}

Follicles were cultured individually in 96-well (V-shaped bottom) plates (Bibby Sterlin, Stone, UK) in $250 \mu \mathrm{l}$ culture medium (McCoy's 5A Medium) with bicarbonate supplemented with HEPES $(20 \mathrm{mM})$, Fraction V BSA $(0.1 \%)$, L-glutamine $(3 \mathrm{mM})$, penicillin $(100 \mathrm{IU} / \mathrm{ml})$, streptomycin $(0.1 \mathrm{mg} / \mathrm{ml})$, transferrin $(2.5 \mu \mathrm{g} / \mathrm{ml})$, selenium $(4 \mathrm{ng} / \mathrm{ml})$, androstenedione $\left(10^{-7} \mathrm{M}\right)$, insulin $(10 \mathrm{ng} / \mathrm{ml})$ and L-ascorbic acid sodium salt $(50 \mu \mathrm{g} / \mathrm{ml})$, all obtained from Sigma. The culture medium described in this current study was originally developed for the culture of ovine and bovine granulosa cells (Campbell et al. 1996, Gutierrez et al. 1997), and was subsequently modified for the culture of bovine preantral follicles (Gutierrez et al. 2000, McCaffery et al. 2000, Thomas et al. 2001). Control groups were cultured in culture medium alone, whereas treatment groups were cultured in culture medium supplemented with either $10 \mathrm{ng} / \mathrm{ml}$ or $1 \mu \mathrm{g} / \mathrm{ml}$ human recombinant IGF-I (Sigma). The lower dose of $10 \mathrm{ng} / \mathrm{ml}$ IGF-I represented a physiological dose that would be able to bind to the IGFBPs, and would therefore be regulated by the level of IGFBPs present. The higher dose of $1 \mu \mathrm{g} / \mathrm{ml}$ IGF-I was designed to swamp the IGFBPs present, allowing IGF-I to bypass the regulatory mechanisms and hence bind freely to IGF receptors. Plates were incubated for 2, 4 or 6 days in a sterile humidified atmosphere with $5 \% \mathrm{CO}_{2}$ at $37^{\circ} \mathrm{C}$. Half of the culture medium was replaced every day, and this conditioned medium was stored at $-20^{\circ} \mathrm{C}$ for subsequent oestradiol analyses. Follicle diameters were measured with a crossed micrometer (basement membrane to basement membrane) under the dissection microscope.

\section{Histological assessment}

At the end of the culture period, follicles were fixed in $4 \%$ paraformaldehyde and dehydrated in graded alcohols, embedded in paraffin wax, sectioned at $6 \mu \mathrm{m}$ thickness 
and mounted on Superfrost Plus microscope slides (VWR International, Poole, UK).

Oocyte health observations were made under the light microscopes. An oocyte was classed as degenerate if it was misshapen or contained no germinal vesicle, and healthy oocytes were classed by having normal morphology and an intact germinal vesicle.

\section{Detection of oestradiol in culture medium}

Medium from the three treatments groups in all size ranges of follicles was analysed for oestradiol content as previously described by Thomas et al. (2003). Briefly, biotinylated oestradiol, follicle-conditioned medium, oestradiol standards and a 1:50000 dilution of primary antibody, made up in $200 \mu$ l of assay buffer, was added to precoated wells of the microtitre plate incubated overnight at $4{ }^{\circ} \mathrm{C}$ and then washed $(X 4)$ in a wash buffer before addition of $100 \mu \mathrm{l}$ assay buffer containing $100 \mathrm{ng} / \mathrm{ml}$ europium-labelled streptavidin (Perkin-Elmer Life Sciences, Newcastle upon Tyne, UK) followed by incubation at room temperature for $1 \mathrm{~h}$ with shaking. The plates were washed $(\times 4)$ in wash buffer before addition of $200 \mu \mathrm{l}$ DELFIA enhancement solution (Perkin-Elmer Life Sciences) to each well of the microtitre plate, and incubated for a further $5 \mathrm{~min}$ with shaking at room temperature. The plates were analysed by time-resolved fluorimetry. The emission and excitation wavelengths were 615 and $340 \mathrm{~nm}$ respectively with a time delay of $400 \mu \mathrm{s}$. The inter- and intra-assay coefficients of variation were 13.2 and $9.6 \%$ respectively. The minimum detectable level was $8.5 \mathrm{pg}$ oestradiol per well.

\section{Immunohistochemistry}

The expression of IGFBP-2 was detected in follicles cultured for 6 days. Antigen retrieval was performed by placing fixed sections $(4 \mu \mathrm{m})$ in $0.01 \mathrm{M}$ citrate buffer $(2 \times 5 \mathrm{~min}(600 \mathrm{~W}))$, and slides were left for $20 \mathrm{~min}$ at room temperature before being washed in PBS ( $2 \times 5 \mathrm{~min})$. Endogenous peroxidase was blocked by placing sections in $1 \%$ hydrogen peroxide for $10 \mathrm{~min}$, followed by washing $(2 \times 5 \mathrm{~min}$ in PBS). The rabbit antibovine IGFBP-2 antiserum (Upstate Biotechnology, Lake Placid, NY, USA) was diluted 1:200 before use. After probing with primary antibody, the sections were washed and stained with goat antirabbit IgG labelled with horseradish peroxidase (1:100) (Sigma). Replacing primary antibody with normal rabbit serum, or saturating the primary antibody with antigen (recombinant bovine IGFBP-2 $(31 \mathrm{kDa})(1 \mathrm{ng} / \mathrm{ml})$ (GroPep, Adelaide, Australia)), detected non-specific binding. Furthermore, immunoblotting by the IGFBP-2 antibody revealed that it detected native IGFBP-2 added to medium and, furthermore, picked up only one band in bovine follicular fluid whose molecular mass corresponded to that of IGFBP-2.

\section{In situ hybridisation}

Details of the procedure used have been described by Armstrong et al. $(1998,2002)$. The expression of IGFBP-2 was detected in follicles in all size ranges, cultured for 2, 4 and 6 days. Sections $(6 \mu \mathrm{m})$ were dehydrated, fixed and probed with ${ }^{35}$ S-labelled IGFBP-2 riboprobe. After the final high stringency wash, the sections were dipped in autoradiographic K2 photographic emulsion (Ilford, Mobberley, UK) and exposed for 6 weeks at $4{ }^{\circ} \mathrm{C}$. Sections were developed (Kodak D-19, Edinburgh, UK) and fixed with Hypam (Ilford) before staining in haematoxylin and eosin. The sections were finally mounted in DPX mountant ( $\mathrm{R}$ A Lamb, Eastbourne, UK) before microscopic examination by both light- and dark-field illumination.

\section{Image analysis}

The intensity of the in situ hybridisation signal was analysed by the NIH Image system (National Institutes of Health, Bethesda, MD, USA). The number of graphic pixels occupied by silver grains (identified by a set grey threshold) within a defined area of the tissue section was counted and presented as a percentage of the total pixel number within the defined area. The hybridisation intensity, therefore, was the percentage of occupied pixels to total pixels within a defined area of the tissue. Background hybridisation intensity, measured with the sense RNA probes, was subtracted from the measurements obtained with the antisense probes to give the final hybridisation signal. Within each follicle, three separate fields (for granulosa cells) were analysed.

\section{Immunohistochemistry analysis}

The section containing the oocyte nucleolus or, if this was absent, the largest cross-section of the oocyte was used for observations. The total number of granulosa cells showing staining and no staining for IGFBP-2 protein was recorded for each follicle. The number of granulosa cells expressing IGFBP-2 protein was expressed as a percentage of the total granulosa cells present for each follicle. No significant difference was found between treatment groups in the mean percentage of granulosa cells exhibiting staining for IGFBP-2 protein. Therefore, the actual total number of follicles showing expression for IGFBP-2 in their granulosa cells or oocyte was calculated as a percentage of the total number of follicles analysed, and comparisons were made between treatment groups.

\section{Statistical analysis}

Mean follicle diameters and oestradiol production for each day were compared between experimental groups by repeated-measures ANOVA (general linear model), with subsequent Tukey's test for individual comparisons between groups. 
The intensity of staining for mRNA IGFBP-2 in granulosa cells was compared between days and treatment groups by ANOVA.

The total number of follicles exhibiting staining for IGFBP-2 protein, and those showing no staining for IGFBP-2 protein in their granulosa cells or oocytes in each treatment group, was also recorded. The number of follicles showing staining for IGFBP-2 protein in their granulosa cells or oocytes was calculated as a percentage of the total number of follicles and displayed as bar charts. Percentages were compared by two-proportion (test and confidence interval) analysis.

\section{Results}

\section{Follicle growth}

There was a significant increase in follicular diameter during culture in all treatment groups $(P<0.01)$. Follicles in the smallest size range $(165-215 \mu \mathrm{m})$ cultured in the presence of $1 \mu \mathrm{g} / \mathrm{ml}$ IGF-I showed a significant increase in follicle diameter by day 4 compared with follicles cultured in the control medium $(P<0.01)$. There was no significant difference in follicle growth found between treatment groups within the other two size ranges of follicles (216-280 and 281-380 $\mu \mathrm{m})$ (Fig. 1a-c).

\section{Oestradiol production}

Oestradiol production increased significantly in all treatment groups during culture $(P<0.01)$. A significant increase in oestradiol production was observed by day 6 in all of the size ranges, in follicles cultured in the presence of $1 \mu \mathrm{g} / \mathrm{ml}$ IGF-I $(P<0.05)$ (Fig. 2a-c). This significant increase in oestradiol production brought about by the presence of $1 \mu \mathrm{g} / \mathrm{ml} \mathrm{IGF-I} \mathrm{was} \mathrm{related} \mathrm{to} \mathrm{the} \mathrm{size} \mathrm{of} \mathrm{the}$ follicles; the largest follicles $(281-380 \mu \mathrm{m})$ exhibited the increase faster than the medium-sized follicles $(216-280 \mu \mathrm{m})$, and the medium-sized follicles showed the increase sooner than the smallest $(165-215 \mu \mathrm{m})$ follicles.

\section{Oocyte health}

No significant difference in the percentage of degenerate oocytes was observed in the two size ranges, 165-215 and $216-280 \mu \mathrm{m}$. The percentage of follicles containing degenerate oocytes at the end of the culture was significantly higher in the largest size range $(281-380 \mu \mathrm{m})$ cultured in the control treatment group than in day-0, $10 \mathrm{ng} / \mathrm{ml}$ IGF-I and $1 \mu \mathrm{g} / \mathrm{ml}$ IGF-I $(P<0.05)$ treatment groups (Fig. 3).

\section{Effect of IGF-I on the level of expression of IGFBP-2 ( $m R N A)$ in granulosa cells and oocytes}

mRNA IGFBP-2 was observed in the granulosa cells and oocyte of follicles on all days, in all treatment groups and in all size ranges (Fig. 4). Initial analysis showed that there

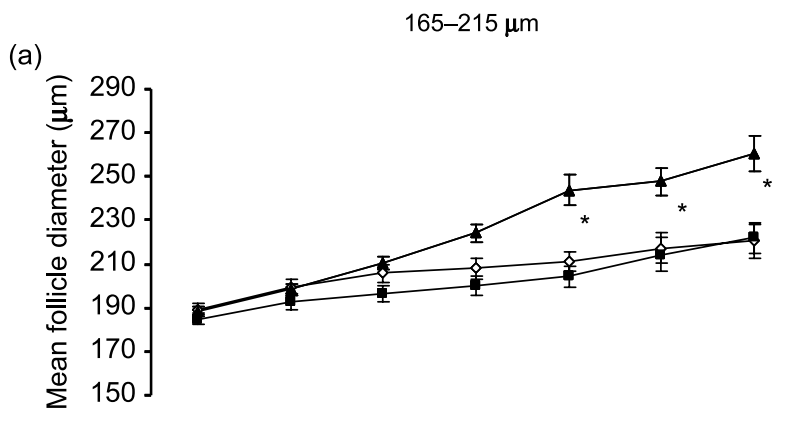

(b)

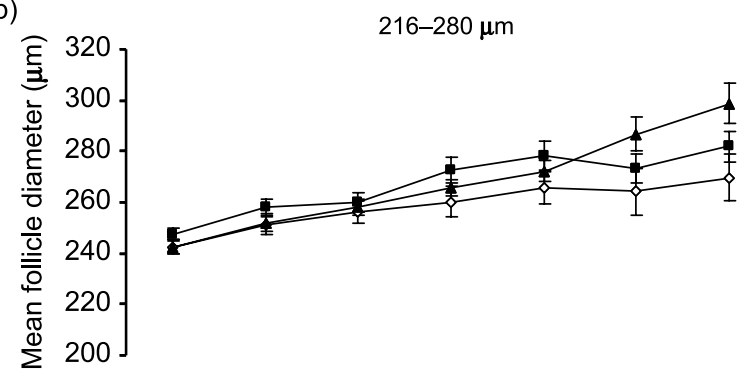

(c)

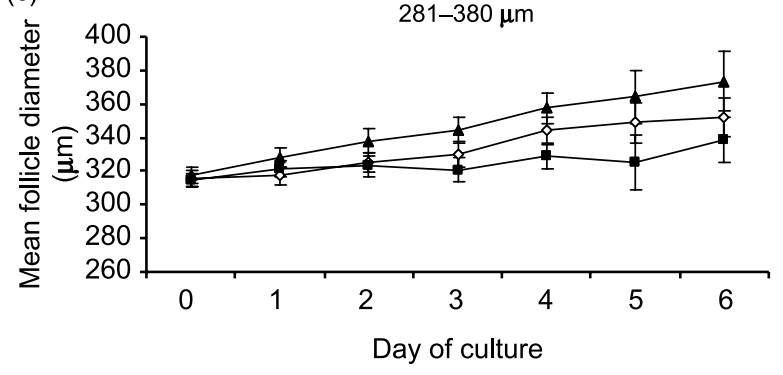

Figure 1 Growth of bovine antral follicles, size ranges (a) 165$215 \mu \mathrm{m}(n=123)$, (b) $216-280 \mu \mathrm{m}(n=128)$ and (c) $281-380 \mu \mathrm{m}$ $(n=105)$, cultured in control medium $(\diamond)$, or in the presence of human recombinant IGF-I $10 \mathrm{ng} / \mathrm{ml}(\boldsymbol{\square})$ or $1 \mu \mathrm{g} / \mathrm{ml}(\boldsymbol{\Lambda})$. Values are mean \pm S.E.M. By the end of the culture (day 6 ), follicles in the smallest size range, cultured in the presence of $1 \mu \mathrm{g} / \mathrm{ml}$ IGF-l, showed a significant $(*)$ increase in follicle diameter compared with follicles cultured in control medium or in the presence of $10 \mathrm{ng} / \mathrm{ml} \mathrm{IGF-I.}$

was no significant difference $(P>0.05)$ in hybridisation intensity between days or treatment groups. Therefore, the effect of IGF-I on IGFBP-2 protein production was studied.

\section{Effect of IGF-I on the percentage of follicles expressing IGFBP-2 (protein) in their granulosa cells}

IGFBP-2 immunoreactivity was observed in the granulosa cells of follicles in all size ranges (Fig. 5). Follicles in the smallest size range $(165-215 \mu \mathrm{m})$ were found not to have a significant difference in the percentage of follicles expressing IGFBP-2 in their granulosa cells. However, a significant decrease in IGFBP-2 expression was found in medium follicles cultured in $1 \mu \mathrm{g} / \mathrm{ml}$ IGF-I compared with the level of expression seen in the day-0 follicles $(P<0.05)$. Furthermore, in the largest size range $(281-380 \mu \mathrm{m})$, there was a significant decrease in the 
(a)

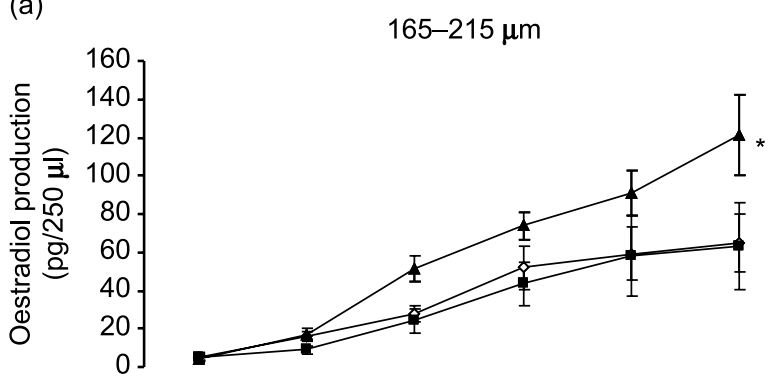

(b)

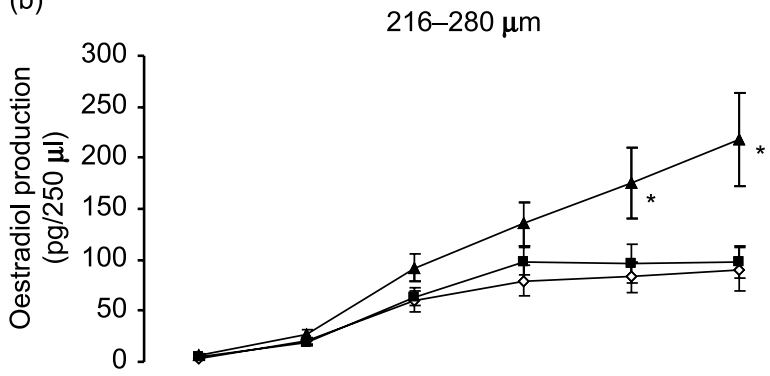

(c)

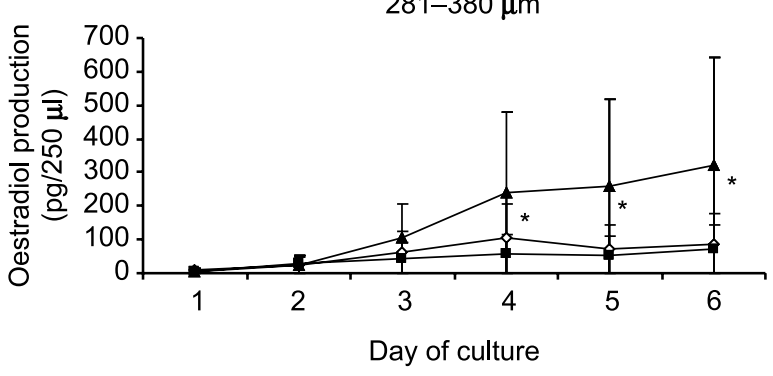

Figure 2 Oestradiol production of bovine antral follicles, size ranges (a) $165-215 \mu \mathrm{m}(n=90)$, (b) $216-280 \mu \mathrm{m}(n=89)$ and (c) $281-$ $380 \mu \mathrm{m}(n=72)$, cultured in control medium $(\diamond)$, or in the presence of IGF-I $10 \mathrm{ng} / \mathrm{ml}(\boldsymbol{\square})$, or $1 \mu \mathrm{g} / \mathrm{ml}(\boldsymbol{\Lambda})$. Values are mean \pm S.E.M. Follicles in all size ranges and cultured in the presence of $1 \mu \mathrm{g} / \mathrm{ml} \mathrm{IGF-I}$ showed a significant $(*)$ increase in oestradiol production by the end of the culture, compared with follicles cultured in control medium or in the presence of $10 \mathrm{ng} / \mathrm{ml} \mathrm{IGF-I.}$

number of follicles expressing IGFBP-2 in the control and $10 \mathrm{ng} / \mathrm{ml}$ IGF-I treatment groups compared with that seen in the day-0 experimental group $(P<0.05)$. Follicles cultured with $1 \mu \mathrm{g} / \mathrm{ml}$ IGF-I were found to maintain the level of expression seen in the day-0 follicles, and therefore had a significantly higher percentage of follicles expressing IGFBP-2 than those seen in the control and $10 \mathrm{ng} / \mathrm{ml}$ IGF-I treatment groups $(P<0.05)$ (Fig. 6).

\section{Effect of IGF-I on the percentage of follicles expressing IGFBP-2 (protein) in their oocytes}

IGFBP-2 immunoreactivity was observed in the oocytes of follicles in all size ranges (Fig. 5). No significant difference was found between treatment groups in the percentage of

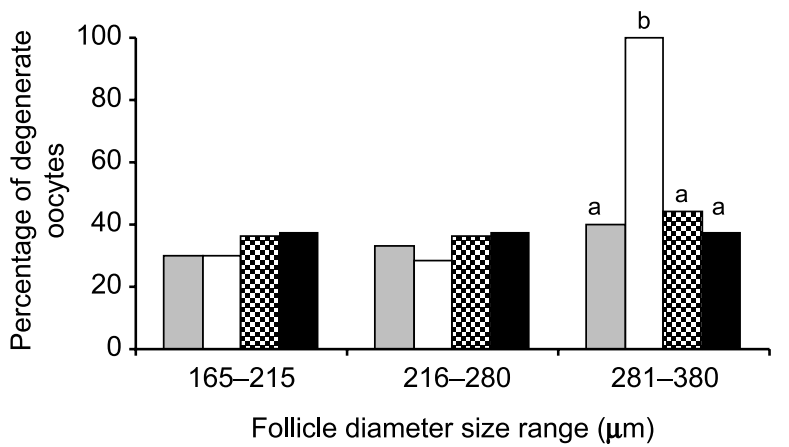

Figure 3 Effect of IGF-I on the percentage of degenerate oocytes observed in follicles after 6-day culture. Day 0: $(\square)$; control: $(\square)$;

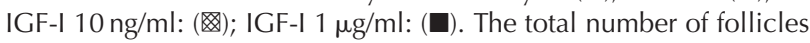
in each size range was as follows: $n=39$ for $165-215 \mu \mathrm{m}, n=38$ for $216-280 \mu \mathrm{m}$ and $n=31$ for $281-380 \mu \mathrm{m}$. Values are the number of degenerate oocytes displayed as a percentage of the total oocytes analysed. No significant difference in the percentage of oocyte degeneration between treatment groups in the size ranges 165-215 and $216-280 \mu \mathrm{m}$ was observed. However, follicles in the larger size range $(281-380 \mu \mathrm{m})$ cultured in control medium had significantly more degenerate oocytes than day-0, $10 \mathrm{ng} / \mathrm{ml} \mathrm{IGF-I} \mathrm{and} 1 \mu \mathrm{g} / \mathrm{ml}$ IGF-I $(P<0.05)$ treatment groups. Different superscripts denote statistically significant differences $(P<0.05)$.

follicles expressing IGFBP-2 in their oocytes in follicle groups with a small and medium-size range (165-215 and 216-280 $\mu \mathrm{m})$. However, a significant decrease in IGFBP-2 expression was found in the largest size range $(281-380 \mu \mathrm{m})$ of follicles cultured in the control or $10 \mathrm{ng} / \mathrm{ml} \mathrm{IGF-I} \mathrm{treatment} \mathrm{groups}(P<0.01)$ (Fig. 7).
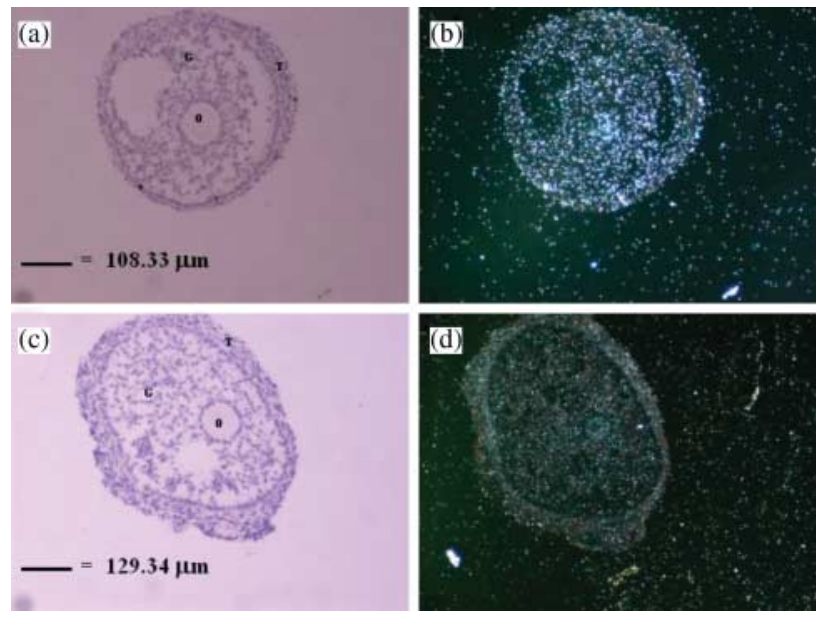

Figure 4 Light-field illumination (a and c) and dark-field illumination of bovine ovarian follicles on day 6 of culture hybridised with antisense ( $\mathrm{a}$ and $\mathrm{b}$ ) and sense ( $\mathrm{c}$ and d) riboprobes for IGFBP-2 mRNA detection. O: oocyte; G: granulosa cells; T: theca cells. Intense hybridisation was found in the granulosa cells and oocyte of follicles hybridised with antisense ${ }^{35}$ S-IGFBP-2 riboprobe (b). No intense staining was found in follicles hybridised with sense ${ }^{35}$ S-IGFBP-2 riboprobe $(\mathrm{d})$. 

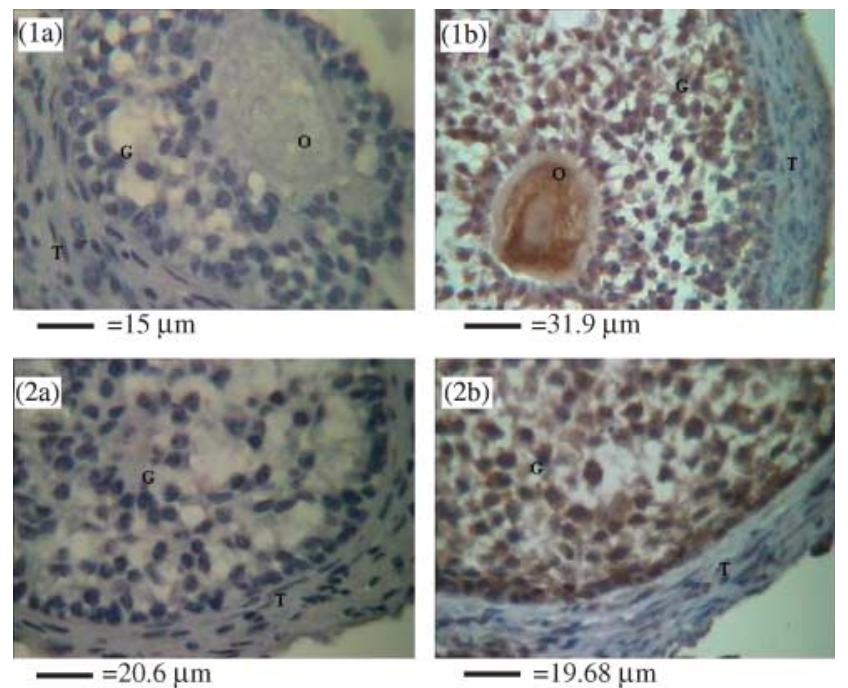

Figure 5 Histological sections of bovine ovarian follicles on day 6 of culture after immunocytochemistry with (a) normal rabbit serum or (b) an antibody raised against bovine recombinant insulin-like growth factor binding protein-2 (IGFBP-2). O: oocyte; G: granulosa cells; $\mathrm{T}$ : theca cells. 1a and b: oocyte, granulosa and theca cells; $2 \mathrm{a}$ and b: granulosa and theca cells.

\section{Discussion}

Previous work has outlined the involvement of IGFBP-2 in the regulation of IGF-I bioavailability (Perks \& Wathes 1996, Armstrong et al. 1998, 2002, Yuan et al. 1998, Monget et al. 2002). It has been hypothesised that IGFBP-2 present in early stages of follicle growth will bind

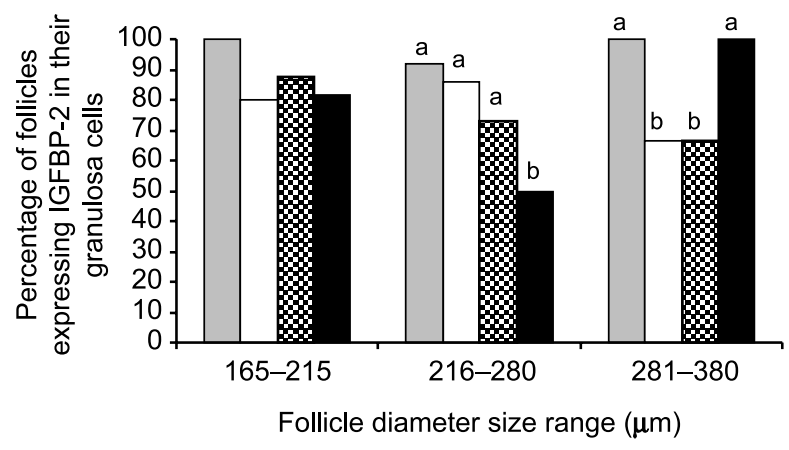

Figure 6 Effect of IGF-I on the percentage of follicles expressing IGFBP-2 (protein) in their granulosa cells on day 6 of culture. Day 0:

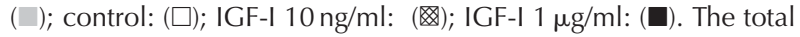
number of follicles in each size range was as follows: $n=39$ for $165-215 \mu \mathrm{m}, n=38$ for $216-280 \mu \mathrm{m}$ and $n=31$ for $281-380 \mu \mathrm{m}$. Values are the mean percentage of follicles showing staining for IGFBP-2 in their granulosa cells for each treatment group within each size range. A significant decrease was found in the follicles cultured in $1 \mu \mathrm{g} / \mathrm{ml}$ IGF-I with a size range of $216-280 \mu \mathrm{m}(P<0.05)$. Follicles in the size group $281-380 \mu \mathrm{m}$ showed a decrease in IGFBP-2 expression when cultured in the control or $10 \mathrm{ng} / \mathrm{ml} \mathrm{IGF-I} \mathrm{treatment}$ groups $(P<0.05)$. Follicles cultured with $1 \mu \mathrm{g} / \mathrm{ml}$ IGF-I had a significantly higher level of expression than that seen in the control and $10 \mathrm{ng} / \mathrm{ml} \mathrm{IGF-I} \mathrm{treatment} \mathrm{groups}(P<0.05)$. Different superscripts denote statistically significant differences $(P<0.05)$.

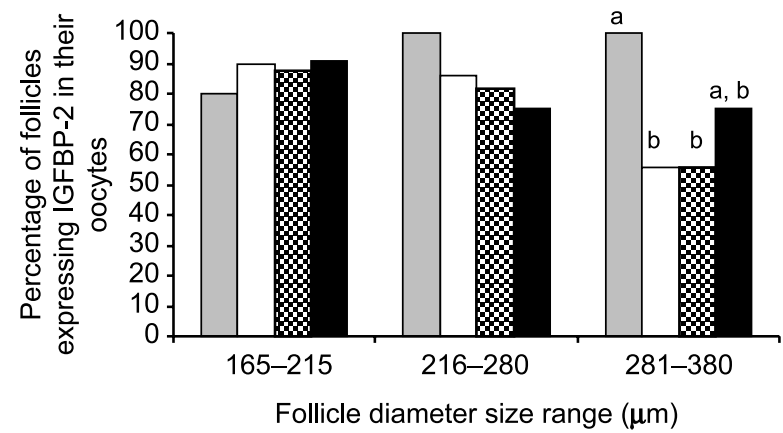

Figure 7 Effect of IGF-I on the percentage of follicles expressing IGFBP-2 (protein) in their oocytes on day 6 of culture. Day 0: ( $\square$ );

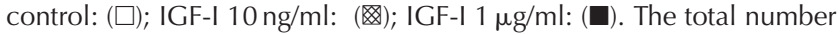
of follicles in each size range was as follows: $n=39$ for $165-$ $215 \mu \mathrm{m}, n=38$ for $216-280 \mu \mathrm{m}$ and $n=31$ for $281-380 \mu \mathrm{m}$. Values are the mean percentage of follicles showing staining for IGFBP-2 in their oocytes for each treatment group within each size range. A significant decrease in IGFBP-2 expression was found in the largest size range of follicles cultured in the control or $10 \mathrm{ng} / \mathrm{ml} \mathrm{IGF-I}$ treatment groups $(P<0.01)$. Different superscripts denote statistically significant differences $(P<0.05)$.

any IGF arriving from the circulation or adjacent antral follicles and regulate its access to the type 1 IGF receptors found in the oocytes and granulosa cells (Armstrong et al. 2002). This study has confirmed that IGFBP-2 (mRNA and protein) is expressed in the oocytes and granulosa cells of early antral follicles. The novel use of varying concentrations of IGF-I as a way to bypass the IGFBPs has highlighted a key role for IGF-I at this stage of follicular development in both granulosa cell differentiation and proliferation. In addition, the level of IGF-I available to a follicle can have a direct affect on the level of expression of IGFBP-2, and hence the availability of IGF-I. Furthermore, these regulatory effects appear to be dependent on the stage of follicle development.

Since the type 1 IGF receptor is present in oocytes and granulosa cells of bovine preantral and early antral follicles (Armstrong et al. 2000), removal of the regulatory influence of IGFBP-2 in vitro may allow a direct action of IGF-I on the developing follicle. In this study, the follicles cultured in medium supplemented with $1 \mu \mathrm{g} / \mathrm{ml}$ IGF-I would be expected to be exposed to the actions of IGF-I, as, at this concentration, the regulation of IGF-I by its binding proteins would be bypassed, and IGF-I would have the potential to act via the IGF receptors. It is likely that high concentrations of IGF-I, while swamping the IGFBPs, would also downregulate the type 1 IGF receptors. Recombinant IGF-I increases bovine preantral follicle and oocyte diameter in vitro (Itoh et al. 2002), and long R3-IGF-I (LR3 IGF-I), an analogue which does not bind to binding proteins, has aided in the formation of the antrum (Gutierrez et al. 2000). However, it is evident that regulation by IGFBPs of IGF-I is beneficial for normal oocyte development in preantral follicles, as inappropriate exposure of preantral follicles to IGF-I has detrimental 
effects on oocyte health (McCaffery et al. 2000). In addition to IGFs exerting an action through their own receptors, under certain conditions they can also exert an action via insulin receptors (Hwa et al. 1999), although this interaction is of a lower affinity than that of insulin for its own receptor. Under certain circumstances, the insulin receptor may mediate some of the biological actions of the IGFs (Hwa et al. 1999, LeRoith 2000). The IGF-I receptors would have been overwhelmed by IGF-I when the high dose $(1 \mu \mathrm{g} / \mathrm{ml})$ of IGF-I was present. Therefore, a possible hypothesis is that, under these conditions, the IGF-I may have been able to mediate its actions via the insulin receptors, as well as the type 1 IGF receptor. This would explain the significant stimulatory effect on the growth of the early antral follicles in the size range $165-215 \mu \mathrm{m}$ and the significant increase in oestradiol production seen in all size ranges of follicles. Hence, elucidation of the mechanisms involved in controlling the expression of IGFBPs during late preantral/early antral follicle development would be beneficial when developing in vitro culture systems for mammalian follicles.

We have shown here that the growth of follicles at an immature stage of development is influenced by direct access to IGF-I; however, the more mature follicles are unaffected by the exposure to IGF-I. Follicles at all stages of development exhibit a significant increase in oestradiol production, with the most mature follicles showing the increase earliest in culture. This implies that, as the follicles mature, they undergo rapid differentiation rather than proliferation, thereby increasing oestradiol production and aiding their chance of escaping follicular atresia. Previous work on bovine ovarian function has found the effect of IGF-I to be influenced by the differentiated state of the follicle (Gutierrez et al. 1997). IGF-I has been shown to stimulate oestradiol production by granulosa cells from small antral follicles $(<4 \mathrm{~mm}$ in diameter), whereas oestradiol production was not stimulated in granulosa cells from large follicles $(4-8$ and $\geq 8 \mathrm{~mm}$ in diameter) (Gutierrez et al. 1997). However, oestradiol production in granulosa cells from ovine antral follicles (from 2 to $\geq 3.5 \mathrm{~mm}$ in diameter) was found to be stimulated by
IGF-I at concentrations of 1 and $10 \mathrm{ng} / \mathrm{ml}$ but suppressed at the higher dose of $100 \mathrm{ng} / \mathrm{ml}$ (Campbell et al. 1996).

IGF-I is known to stimulate nuclear maturation of cumulus-enclosed oocytes (Lorenzo et al. 1994, Sirotkin et al. 2000) and improve early embryonic development (Pawshe et al. 1998, Sirisathien et al. 2003, Sirisathien \& Brackett 2003). However, in contrast to work carried out previously on bovine preantral follicles - in which the LR3 IGF-I analogue (which does not bind to IGFBPs) was found to have a detrimental effect on oocyte health (McCaffery et al. 2000) - IGF-I was not found to have a detrimental effect on oocyte health at this later developmental stage. In fact, the presence of IGF-I even at the high concentration was found to be beneficial in maintaining oocyte health once the follicle has reached a more mature stage of development (antral follicles with a follicle diameter of $281-380 \mu \mathrm{m})$.

IGFBP expression has been found to be influenced by the presence of various hormones and growth factors (Sakal et al. 1992, Chamberlain \& Spicer 2001, Voge et al. 2004). In particular, IGF has been shown to play a role in the control of ovine granulosa cell IGFBP-2 production, in which both FSH and IGF-I are necessary for maximum production of IGFBP-2 (Armstrong et al. 1996). Grimes and Hammond (1992) showed that IGF-I in a dosedependent manner significantly stimulated the production of IGFBP-2 and -3 in granulosa cells taken from porcine follicles $4-6 \mathrm{~mm}$ in diameter. Furthermore, the synthetic analogue, LR3-IGF-I, which has a low affinity for IGFBPs, was shown to have a significantly greater potency in stimulating the production of these IGFBPs than IGF-I. Taken together, these results suggest that IGFBP production is regulated by the type 1 IGF receptor, and that an increase in IGF activity stimulates the production of IGFBPs, which in turn reduces the bioavailability of the IGFs. The results found in this current study (summarised in Table 1) support the finding that IGF-I can stimulate IGFBP-2 expression in a dose-dependent manner. It was found that the percentage of follicles expressing IGFBP-2 in their granulosa cells in the largest size group decreased when IGF-I was absent or the concentration present was low. By contrast, when the follicles were cultured in a high

Table 1 Summary of the effect of human recombinant IGF-I on follicle proliferation, differentiation and IGFBP-2 (protein) expression in early antral bovine ovarian follicles cultured in vitro.

\begin{tabular}{|c|c|c|c|}
\hline \multirow[b]{2}{*}{ Effect of IGF-I on: } & \multicolumn{3}{|c|}{ Follicle diameter size range } \\
\hline & $165-215 \mu \mathrm{m}$ & $216-280 \mu \mathrm{m}$ & $281-380 \mu \mathrm{m}$ \\
\hline $\begin{array}{l}\text { Follicle proliferation } \\
\text { (increase in follicle diameter) }\end{array}$ & $\begin{array}{l}\uparrow \text { when cultured with } \\
1 \mu \mathrm{g} / \mathrm{ml} \mathrm{IGF-I}\end{array}$ & No effect & No effect \\
\hline $\begin{array}{l}\text { Follicle differentiation } \\
\text { (oestradiol production) }\end{array}$ & $\begin{array}{l}\uparrow \text { when cultured with } \\
1 \mu \mathrm{g} / \mathrm{ml} \mathrm{IGF-I}\end{array}$ & $\begin{array}{l}\uparrow \text { when cultured with } \\
1 \mu \mathrm{g} / \mathrm{ml} \mathrm{IGF-I}\end{array}$ & $\begin{array}{l}\uparrow \text { when cultured with } \\
1 \mu \mathrm{g} / \mathrm{ml} \mathrm{IGF-I}\end{array}$ \\
\hline$\%$ of granulosa cells expressing IGFBP-2 & No effect & No effect & No effect \\
\hline $\begin{array}{l}\% \text { of follicles expressing IGFBP-2 in their } \\
\text { granulosa cells }\end{array}$ & No effect & $\begin{array}{l}\downarrow \text { when cultured with } \\
1 \mu \mathrm{g} / \mathrm{ml} \mathrm{IGF-I}\end{array}$ & $\begin{array}{l}\downarrow \text { when cultured with control } \\
\text { or } 10 \mathrm{ng} / \mathrm{ml} \mathrm{IGF-I}\end{array}$ \\
\hline $\begin{array}{l}\% \text { of follicles expressing IGFBP-2 in } \\
\text { their oocytes }\end{array}$ & No effect & No effect & $\begin{array}{l}\downarrow \text { when cultured with control } \\
\text { or } 10 \mathrm{ng} / \mathrm{ml} \mathrm{IGF-I}\end{array}$ \\
\hline
\end{tabular}


concentration of IGF-I, the high level of expression of IGFBP-2 found in the day-0 follicles was maintained. A possible explanation of these results is that at this stage in development the granulosa cells have differentiated enough to be able to respond to the action of IGF-I by adjusting the expression of IGFBP-2, possibly by a negative feedback mechanism. Furthermore, the oocyte appears to have also developed to a stage where it too can modulate the expression of IGFBP-2 to regulate IGF bioavailability. However, further investigation is required, as the effect of the high concentration of IGF-I on IGFBP-2 could have been mediated via the insulin receptors and thus be an insulin effect.

In conclusion, the stimulatory effects of IGF-I on early bovine follicle proliferation, differentiation and oocyte health were found to be dose and stage dependent. It is now clear that the biological actions of IGF depend in part on the ability of specific proteases to break down the IGF/IGFBP complex and/or the level of expression of the IGFBPs (Giudice 1992). This work has shown that IGF-I can play a role in regulating its own bioavailability by influencing the expression of IGFBP-2. These results suggest that IGF-I may do this through a negative feedback mechanism, which again is stage dependent. The control of local growth factors by regulatory mechanisms needs to be more fully investigated, as it appears to be the key in developing an in vitro culture system that will accelerate follicle development without causing precocious differentiation to occur.

\section{Acknowledgements}

We thank Karen Troup for help with the in situ hybridisation. This work was supported by the Biotechnology and Biological Sciences Research Council (UK). The authors declare that there is no conflict of interest that would prejudice the impartiality of this scientific work.

\section{References}

Armstrong DG \& Webb R 1997 Ovarian follicular dominance: the role of intraovarian growth factors and novel proteins. Reviews in Reproduction 2 139-146.

Armstrong DG, Hogg CO, Campbell BK \& Webb R 1996 Insulin-like growth factor (IGF)-binding protein production by primary cultures of ovine granulosa and theca cells. The effects of IGF-I, gonadotropin, and follicle size. Biology of Reproduction 55 1163-1171.

Armstrong DG, Baxter G, Gutierrez CG, Hogg CO, Glazyrin AL, Campbell BK, Bramley TA \& Webb R 1998 Insulin-like growth factor binding protein-2 and -4 messenger ribonucleic acid expression in bovine ovarian follicles: effect of gonadotropins and developmental status. Endocrinology 139 2146-2154.

Armstrong DG, Gutierrez CG, Baxter G, Glazyrin AL, Mann GE, Woad KJ, Hogg CO \& Webb R 2000 Expression of mRNA encoding IGF-I, IGF-II and type 1 IGF receptor in bovine ovarian follicles. Journal of Endocrinology 165 101-113.

Armstrong DG, Baxter G, Hogg CO \& Woad KJ 2002 Insulin-like growth factor (IGF) system in the oocyte and somatic cells of bovine preantral follicles. Reproduction 123 789-797.

Baker J, Hardy MP, Zhou J, Bondy C, Lupu F, Bellve AR \& Efstratiadis A 1996 Effects of an Igf1 gene null mutation on mouse reproduction. Molecular Endocrinology 10 903-918.
Besnard N, Pisselet C, Monniaux D, Locatelli A, Benne F, Gasser F, Hatey F \& Monget P 1996 Expression of messenger ribonucleic acids of insulin-like growth factor binding protein-2, -4 , and -5 in the ovine ovary: localization and changes during growth and atresia of antral follicles. Biology of Reproduction 55 1356-1367.

Campbell BK, Scaramuzzi RJ \& Webb R 1996 Induction and maintenance of oestradiol and immunoreactive inhibin production with FSH by ovine granulosa cells cultured in serum-free media. Journal of Reproduction and Fertility 106 7-16.

Campbell BK, Baird DT \& Webb R 1998 Effects of dose of LH on androgen production and luteinization of ovine theca cells cultured in a serum-free system. Journal of Reproduction and Fertility $11269-77$

Chamberlain CS \& Spicer LJ 2001 Hormonal control of ovarian cell production of insulin-like growth factor binding proteins. Molecular and Cellular Endocrinology 182 69-81.

Giudice LC 1992 Insulin-like growth factors and ovarian follicular development. Endocrine Reviews 13 641-669.

Grimes RW \& Hammond JM 1992 Insulin and insulin-like growth factors (IGFs) stimulate production of IGF-binding proteins by ovarian granulosa cells. Endocrinology 131 553-558.

Guler A, Poulin N, Mermillod P, Terqui M \& Cognie Y 2000 Effect of growth factors, EGF and IGF-I, and estradiol on in vitro maturation of sheep oocytes. Theriogenology 54 209-218.

Gutierrez CG, Campbell BK \& Webb R 1997 Development of a longterm bovine granulosa cell culture system: induction and maintenance of estradiol production, response to follicle-stimulating hormone, and morphological characteristics. Biology of Reproduction 56 608-616.

Gutierrez CG, Ralph JH, Telfer EE, Wilmut I \& Webb R 2000 Growth and antrum formation of bovine preantral follicles in longterm culture in vitro. Biology of Reproduction 62 1322-1328.

Hwa V, Oh Y \& Rosenfeld RG 1999 The insulin-like growth factorbinding protein (IGFBP) superfamily. Endocrine Reviews 20 $761-787$.

Itoh T, Kacchi M, Abe H, Sendai Y \& Hoshi H 2002 Growth, antrum formation, and estradiol production of bovine preantral follicles cultured in a serum-free medium. Biology of Reproduction $\mathbf{6 7}$ 1099-1105.

LeRoith D 2000 Insulin-like growth factor I receptor signaling - overlapping or redundant pathways? Endocrinology 141 1287-1288.

Lorenzo PL, Illera MJ, Illera JC \& Illera M 1994 Enhancement of cumulus expansion and nuclear maturation during bovine oocyte maturation in vitro by the addition of epidermal growth factor and insulin-like growth factor I. Journal of Reproduction and Fertility $101697-701$.

Louhio H, Hovatta O, Sjoberg J \& Tuuri T 2000 The effects of insulin, and insulin-like growth factors I and II on human ovarian follicles in long-term culture. Molecular Human Reproduction 6 694-698.

McCaffery FH, Leask R, Riley SC \& Telfer EE 2000 Culture of bovine preantral follicles in a serum-free system: markers for assessment of growth and development. Biology of Reproduction 63 267-273.

Monget P, Besnard N, Huet C, Pisselet C \& Monniaux D 1996 Insulin-like growth factor-binding proteins and ovarian folliculogenesis. Hormone Research 45 211-217.

Monget P, Fabre S, Mulsant P, Lecerf F, Elsen JM, Mazerbourg S, Pisselet C \& Monniaux D 2002 Regulation of ovarian folliculogenesis by IGF and BMP system in domestic animals. Domestic Animal Endocrinology 23 139-154.

Pawshe CH, Rao KB \& Totey SM 1998 Effect of insulin-like growth factor I and its interaction with gonadotropins on in vitro maturation and embryonic development, cell proliferation, and biosynthetic activity of cumulus-oocyte complexes and granulosa cells in buffalo. Molecular Reproduction and Development 49 $277-285$

Perks CM \& Wathes DC 1996 Expression of mRNAs for insulin-like growth factor binding proteins-2, -3 and -4 in the ovine ovary throughout the oestrous cycle. Journal of Endocrinology 151 $241-249$ 
Perks CM, Denning-Kendall PA, Gilmour RS \& Wathes DC 1995 Localization of messenger ribonucleic acids for insulin-like growth factor I (IGF-I), IGF-II, and the type 1 IGF receptor in the ovine ovary throughout the estrous cycle. Endocrinology 136 5266-5273.

Perks CM, Peters AR \& Wathes DC 1999 Follicular and luteal expression of insulin-like growth factors I and II and the type 1 IGF receptor in the bovine ovary. Journal of Reproduction and Fertility $116157-165$

Poretsky L, Cataldo NA, Rosenwaks Z \& Giudice LC 1999 The insulinrelated ovarian regulatory system in health and disease. Endocrine Reviews 20 535-582.

Sakal E, Gertler A, Aflalo L \& Meidan R 1992 Characterization of insulin-like growth factor binding proteins secreted by cultured bovine theca and granulosa cells. Molecular and Cellular Endocrinology 90 39-46.

Sirisathien S \& Brackett BG 2003 TUNEL analyses of bovine blastocysts after culture with EGF and IGF-I. Molecular Reproduction and Development 65 51-56.

Sirisathien S, Hernandez-Fonseca HJ \& Brackett BG 2003 Influences of epidermal growth factor and insulin-like growth factor-I on bovine blastocyst development in vitro. Animal Reproduction Science 77 21-32.

Sirotkin AV, Dukesova J, Makarevich AV, Kubek A \& Bulla J 2000 Evidence that growth factors IGF-I, IGF-II and EGF can stimulate nuclear maturation of porcine oocytes via intracellular protein kinase A. Reproduction, Nutrition, Development 40 559-569.

Spicer LJ \& Echternkamp SE 1995 The ovarian insulin and insulinlike growth factor system with an emphasis on domestic animals. Domestic Animal Endocrinology 12 223-245.

Thomas FH, Leask R, Srsen V, Riley SC, Spears N \& Telfer EE 2001 Effect of ascorbic acid on health and morphology of bovine preantral follicles during long-term culture. Reproduction 122 487-495.

Thomas FH, Armstrong DG \& Telfer EE 2003 Activin promotes oocyte development in ovine preantral follicles in vitro. Reproductive Biology and Endocrinology 176.
Voge JL, Santiago CA, Aad PY, Goad DW, Malayer JR \& Spicer LJ 2004 Quantification of insulin-like growth factor binding protein mRNA using real-time PCR in bovine granulosa and theca cells: effect of estradiol, insulin, and gonadotropins. Domestic Animal Endocrinology 26 241-258.

Wandji SA, Pelletier G \& Sirard MA 1992 Ontogeny and cellular localization of ${ }^{125}$ I-labeled insulin-like growth factor-I, ${ }^{125}$ I-labeled follicle-stimulating hormone, and ${ }^{125}$ I-labeled human chorionic gonadotropin binding sites in ovaries from bovine fetuses and neonatal calves. Biology of Reproduction 47 814-822.

Webb R, Campbell BK, Garverick HA, Gong JG, Gutierrez CG \& Armstrong DG 1999 Molecular mechanisms regulating follicular recruitment and selection. Journal of Reproduction and Fertility. Supplement $\mathbf{5 4}$ 33-48.

Yuan W, Bao B, Garverick HA, Youngquist RS \& Lucy MC 1998 Follicular dominance in cattle is associated with divergent patterns of ovarian gene expression for insulin-like growth factor (IGF)-I, IGF-II, and IGF binding protein-2 in dominant and subordinate follicles. Domestic Animal Endocrinology $\mathbf{1 5}$ $55-63$.

Zhao J, Taverne MA, van der Weijden GC, Bevers MM \& Van den HR 2001 Insulin-like growth factor-I (IGF-I) stimulates the development of cultured rat pre-antral follicles. Molecular Reproduction and Development 58 287-296.

Zhou J, Bievre M \& Bondy CA 2000 Reduced GLUT1 expression in Igf1 - /- null oocytes and follicles. Growth Hormone and IGF Research 10 111-117.

Received 8 February 2005

First decision 18 April 2005

Revised manuscript received 1 December 2005

Accepted 6 December 2005 